\title{
Allooksame? Mediating Visual Cultures of Race on the Web
}

\author{
Lisa Nakamura
}

The Internet presents a real dilemma to postcolonial theorists, writers, and intellectuals; indeed, perhaps to postcolonial theory itself. The range and tone of responses to cyberspace reflect a deep split in the ways that this new communication technology is viewed by non-Western cultures and races. Ziauddin Sardar sees the Internet as a tool of imperialism, and he asserts that it is simply the newest example on a continuum of imperializing practices perpetrated by the West in its ongoing domination of other cultures. He regards cyberspace as a medium that can only transmit imperialistic ideologies; its background in military research and high cost of access makes it intrinsically a Western technology with no potential for resistance by people of color. In short, he sees it as a medium that's inherently flawed by its association with modernity, tropes of colonialism, and hypercapitalism.

His critique is extremely similar in many ways to Chinua Achebe's famous response to Joseph Conrad's Heart of Darkness. There's no turning back from the way that Achebe singlehandedly politicized that text; the Norton Critical Edition of the novel includes it because it's now become part of the discursive field of

Lisa Nakamura is Assistant Professor of Communication Arts and Visual Culture Studies at the University of Wisconsin, Madison. She is the author of Cybertypes: Race, Ethnicity, and Identity on the Internet (Routledge, 2002) and co-editor of Race in Cyberspace (Routledge, 2000). She has published articles on cross-racial roleplaying in Internet chatspaces; race, embodiment, and virtuality in the film The Matrix; and political economies of race and cyberspace in publications such as Women's Review of Books, Unspun: Key Concepts for Understanding the World Wide Web (New York, 2000), The Cybercultures Reader (Routledge, 2000), and The Visual Culture Reader (Routledge, 2002). She is currently working on a new book tentatively entitled Visual Cultures of Race in Cyberspace. She can be reached at lanakamura@wisc.edu. 
postcolonial criticism as well as a virtuoso reading of the text. Achebe demonstrates that Conrad's novel depicts natives as irredeemably Other, as the West's dark side. Sardar says that cyberspace accomplishes the same thing.

On the other hand, many new media collectives in traditionally "media poor" countries who lack widespread access to the Internet strongly assert the usefulness of Internet and computer use in the context of non-Western culture. The Sarai New Media Centre in Delhi is trying to make software for people who are nonliterate as a means to wrest the medium away from cultural elites. Even more importantly, this move away from textual literacy produces expressive forms which are more in line with the culture's distinctive media landscape, thus reducing the dangers of imperializing incursions from the West. Jeebesh Bagchi, Sarai member and a Raqs media collective artist, claims that "India is a song and visual sign board culture" and asks, "What kind of dialogue with this strange and eclectic world do we want to create, not based on domination or populism?" (qtd. in Lovink 212). Envisioning and using the Internet in visual rather than primarily textual ways can be a radically empowering move for non-literate groups.

Seen in this light, the Internet has tremendous potential for challenging colonial regimes of power, particularly those which privilege access to the written word. Sarai asserts that the Internet need not be a manifestation of the West's dark side, but rather it can be retooled as an empowering device for non-Western users. Sarai's emphasis on reaching non-literate users acknowledges the power dynamics associated with literacy. Before there was a digital divide questions of power had always worked themselves out in the written word divide. New electronic mediations that will successfully reach the "people" may do so by detouring around the written word, a particularly appropriate tactic in visual cultures such as India's. As Geert Lovink explains: "So far in India popular culture has been defined by film. There is a tradition in India to interpret society through film" (212).

Shuddhabrata Sengupta, a filmmaker and media practitioner who is also a member of the Raqs Media Collective and a founder of the Sarai New Media Centre in Delhi, articulates some of the complexities of cultural negotiation regarding new media forms in the postcolonial context. In his discussion of the practicalities of using Hindi as an Internet language, he weighs on the one hand the imperatives of "cultural authenticity"-retaining the Hindi character set despite its incompatibilities with existing hardware-against the loss suffered by having to translate Hindi to the Roman character set, which won't accommodate it without expensive equipment which makes it cost-prohibitive in a country where any network connection is already a precious commodity. Sengupta's solution is that that Indians must give up the typographical "purity" of Hindi in order to enter the digital commons. Questions of the postcolonial politics of translation and language are foremost in Sengupta's argument. He writes that even though "the sense of inauthenticity accompanying this stance may produce some discomfort, it at least brings with it a means of entering the digital commons on reasonably fair terms. Once there, we are free to forage for new meanings and new identities" ("Tales of the Commons Culture"). The discourse of "purity" is here weighed against the appeal of the "digital 
commons" and found wanting. The desire for cultural purity implies a drive to keep unproblematic notions of race, identity, gender, and other subject positions untainted by cultural hybridity in any form, from either new media or old. Sengupta is willing to trade a "pure" Internet Hindi for the opportunity to use new media to forge "new meanings and new identities," which will necessarily be hybrid in nature.

Thus, despite their many ideological differences, both Sardar and the Sarai founders seem to agree that the Internet will produce "impure" or "inauthentic" expressive forms. Where they differ is in the question of whether or not this is a trade worth making, and whether it is pragmatic to resist it.

Of course, these are not the only two "postcolonial" positions vis-à-vis the Internet; postcolonial theory is far too complex to produce only two modes of interpretation on this or any subject. To sum it up, however, critics like Sardar are concerned primarily with preserving cultural authenticity and see the medium of cyberspace itself as a vector for Western ideologies, regardless of its content. Bagchi and Sengupta are concerned with providing access to the Internet to people traditionally left out of the global communications loop, and are interested in doing so in ways that are image- rather than text-based. They acknowledge that changing existing Indian linguistic forms to make them computer-friendly may produce an "inauthentic" medium, one that has suffered a loss of identity at the hands of the West. However, their emphasis upon creating a visual Internet for non-literate users seems designed to remedy that particular representational violence, in a sense. I will return to this crucial issue later.

It is difficult to see a middle ground between these two positions. What is quite striking about them, however, is how extremely closely they match up to much older foundational debates in postcolonial theory regarding literary and linguistic imperialism that have been circulating for the last few decades, since the legitimization of postcolonial critique as an academic discipline. Indeed, to use computer talk, in a sense postcolonial theory itself has been ported from literary studies, where it has a strong presence, to other areas, the Internet being the most recent of these. In any event, the similarity of the two debates may prove instructive in regards to questions of the Internet, cultural authenticity, and race in both global and American contexts.

Examinations of the ways that language and literary forms produce power, identity, and "race" as a cultural construct have always been central to postcolonial theory. The works of Ngugi wa Thiongo, Gloria Anzaldua, Chinua Achebe, Ama Ata Aidoo, Salman Rushdie, Homi Bhabha, and Edward Said all privilege the language and the literary as a field of discourse within which the battle over cultural hegemony has been waged. The specific literary techniques and tropes which have produced the "native" in Western literature and the attendant issue of the place that Western languages such as English ought to have in non-Western institutions has been debated for some time now. And just as Sardar and Bagchi/Sengupta split over the issue of the Internet, so too do postcolonial literary critics part ways over the 
appropriateness of Western literary forms and languages in the postcolonial context.

Of course, there is a range of positions over this issue, but Ngugi wa Thiongo and Salman Rushdie's writings typify two opposed ones which align fairly neatly with the poles of thought represented by Sardar and Bagchi/Sengupta. Ngugi's project as a writer and activist is to reclaim indigenous language use as a central aspect of the project of cultural independence. His much-publicized decision to write only in Kikuyu after having produced a large body of well-respected literary works in English arises from his political conviction that language is the "collective memory bank of a people" and that imperial languages such as English participate in the "captivation" of colonized peoples (30), especially when they are used by non-Western novelists as a part of their literary production and work to define a cultural elite which is then Western. He asserts that "when [nations] meet as oppressor and oppressed, as for instance under imperialism, then their languages cannot experience a genuinely democratic encounter. The oppressor nation uses language as a means of enriching itself in the oppressed language" (31). For him, language is ineluctably a "carrier of national cultures" and he holds the line against the attractions of hybridity. ' For Ngugi, African literature must be written in African languages - period. He and Sardar share a commitment to cultural authenticity and a wariness of Western media forms that is based on a deep awareness of the historical abuses of the past (and the present). ${ }^{2}$

Salman Rushdie occupies the other side of this debate. He asserts that "English has become an Indian language" and that "the true Indian literature of the first postcolonial half century has been made in the language the British left behind" ("Damme" 50). Rushdie describes Indian literature written in English (which he terms "Indo-Anglian" literature) in language that evokes commercial discourse about the Internet: he calls English "the most powerful medium of communication in the world" and lauds Anglophone literature as "a means of holding a conversation with [it]" (54). He acknowledges the role of high technologies in this imperative, saying that "the new silicon valley-style boom in computer technology which is transforming the economies of Bangalore and Madras has made English in those cities an even more important language than before" (54). Hence, the economic benefits to using Western media forms is presented as a strong reason that Indians ought to embrace English; Rushdie's position, however, is based upon a much more radical notion, which is that India has "colonized" English rather than the other way around. He anticipates critics such as Ngugi, writing that "for some Indian critics, English-language Indian writing will never be more than a postcolonial anomaly - the bastard child of Empire, sired on India by the departing British. Its continuing use of the old colonial tongue is seen as a fatal flaw that rends it forever inauthentic" (52). Again, this painful sensitivity about the possible loss of cultural purity which characterizes Sarai's stance is weighed against the benefits to be had from entering a "conversation with the world," and the "world" wins. While Sarai acknowledges the possible losses to Hindi identity which Internet adoption may bring about, Rushdie is strikingly unambivalent about the superiority of English as a literary language, especially in the hands of diasporic writers, but also aware of 
accusations that such literature is "deracinated" and "Westernized" (56). And all throughout his discussion in The New Yorker article in which he formulates this position, there is no mention of race whatsoever. ${ }^{3}$

The rift between the two camps in postcolonial literary theory maps well onto the impasse between thinkers in postcolonial Internet theory. On the one hand, some fear miscegenation between media and worry that uneven encounters between "pure" non-Western cultural forms and "tainted" electronic media must necessarily result in a muddled, deracinated mediascape. Others seem to welcome the opportunity that multimedia may give them to produce new cultural forms which are hybrid, multicultural, and by implication multiracial. This is not to say that cultural authenticists are condemning racial muddling or mixing along with media muddling, or saying that one is the effect of the other, but rather that the rhetoric of purity and the discourse of "deracination" must evoke earlier discourses of "biological" purity and racial authenticity. Why are these colonial fears of racial and cultural miscegenation resurfacing in discussions of the Internet and new media?

In a sense this set of concerns is moot, for the Internet is penetrating cultures, markets, ethnic groups, and genders at a tremendous clip in total defiance of what the critics think. ${ }^{4}$ However, the debates within postcolonial theory over language adoption can prove useful in parsing out the ways that new media can seek to avoid a seeming deadlock between contradictory positions. The fact is that there are few, perhaps no, media forms which are "purely" authentic, just as there are few which are homogeneously and uniformly hybrid. Media forms are bumpy, layered, and pitted with the imprint of contact with other cultures; none avoid the mark of imperialist power relations. And the Internet is no different. What the Internet does offer, however, is a range of imagistic and interactive practices that produce a distinctively different mediascape from the world of the static literary text. ${ }^{5}$ The potential of the Internet to transform visual cultures like India's or at least to engage with them in ways that literary texts can't must be examined if we wish to avoid repeating the same arguments regarding cultural purity versus cultural hybridity. This is a Hobson's choice that would be better avoided for a number of reasons, not the least of which it entirely fails to take into account people who are not textually literate in any language, thus perpetuating an analog class and education divide. ${ }^{6}$

As previously noted, media are multifarious, and multimedia are perhaps even more so. If we shift our focus away from the discourse of literary postcolonial theory, we can better perceive the possibilities that the visual culture of the Internet can have for challenging notions of racial and cultural essence and identity. As Lovink writes, "over the last few decades media theory has drawn heavily from literary criticism. Perhaps it is time to reverse the intellectual exchange" (32). Lovink's call for a "radical upgrade of literary criticism" acknowledges that there are aspects of visual culture on-line that can't be adequately thought through using literary models. There is no doubt that images can be just as complicitous with the colonial project as words: they are no more innocent than novels, advertisements, manifestos, or medical taxonomies of racial difference. In fact, the most interesting new work on postcoloniality in recent years has been in the field of visual culture. 
Sander Gilman, Anne McClintock, Nicholas Mirzoeff, and Ella Shohat have all produced fascinating work on the ways visual cultures of empire produce racial hegemonies. ${ }^{7}$ However, websites such as Dyske Suematsu's alllooksame.com effectively employ interactivity and the spectacle of race on-line in ways that offer distinctive forms of resistance to racial and visual categories. It critiques vision itself as a way of understanding race, culture, and the body on- and off-line.

There is a tendency in new media criticism to valorize ethnic identity websites that have an overtly progressive political stance as being more culturally "authentic" (and thus less corrupted by the West) than others. ${ }^{8}$ I chose to examine allooksame.com because it is a space produced by an Asian designer for an Asian and Asian-American audience which debates national and ethnic identities rather than simply affirms them. In addition, alllooksame.com is a comedic site, and thus part of a dramatically underexamined genre which gets next to no critical attention even from net critics.

Dyske Suematsu's alllooksame.com is a weird, weird site. Interacting with it produces a mixture of guilt, fascination, and a lingering feeling of discomfort. In short, it is uncanny (see image 1). The initial screen features the familiar iconography of a scantron exam form with its ranks of numbered oval blanks, along with a "welcome" narrative that reads:

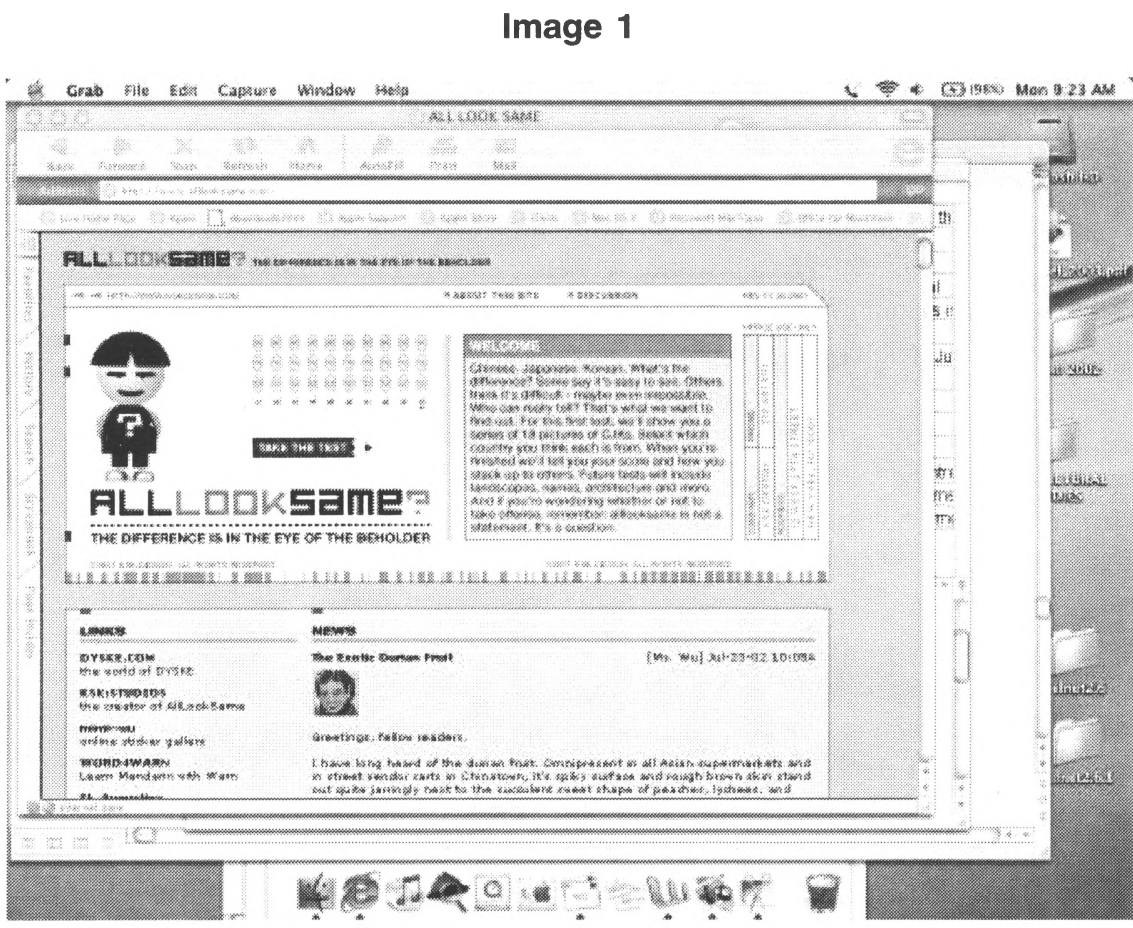


Chinese. Japanese. Korean. What's the difference? Some say it's easy to see. Others think it's difficult-maybe even impossible. Who can really tell? That's what we want to find out. For this first test, we'll show you a series of 18 pictures of CJKs. Select which country you think each is from. When you're finished we'll tell you your score and how you stacked up to others. Future tests will include landscapes, names, architecture, and more. And if you're wondering whether or not to take offense, remember: allooksame is not a statement. It's a question.

After the user completes a short registration form she is routed to the "test," which consists of digital photographs of young men and women. The form requires the user to click one of three boxes in order to move ahead in the site: one must guess whether the photograph is of a Chinese, Japanese, or Korean person. After the user had done this for all 18 images, the site calculates the score; the average score is 7. Users are given the corrected version of their test so they can guess which ones they got "wrong" and are told that they are "OK" if they get a score higher than average (see image 2). Suematsu writes that he designed the site "ultimately as a joke" and that he "didn't mean this site to be some sort of political arena." Despite this, as he writes in an essay to the user, "some people felt that this site would promote racism, or that the site itself is racist. Others felt quite the opposite. I was very surprised to receive many emails with encouraging words from Chinese, Korean, and Japanese people. In some ways, I was expecting to upset many of these people." The wide range of responses to the site demonstrates the ways that this particular kind of interactivity, one which puts the user in the position of a racial profiler of sorts, functions as a nexus for Asians and Asian-Americans to actively consider race as an act of seeing. Most importantly, the low scores that most users get confirm that seeing is not believing; the "truth" about race is not a visual truth, yet one which is persistently envisioned that way. This website is an apparatus which deconstructs the visual culture of race. The confusion this entails-users seem to be radically divided as to what the site signifies-provides a unique inter-

\section{Image 2}

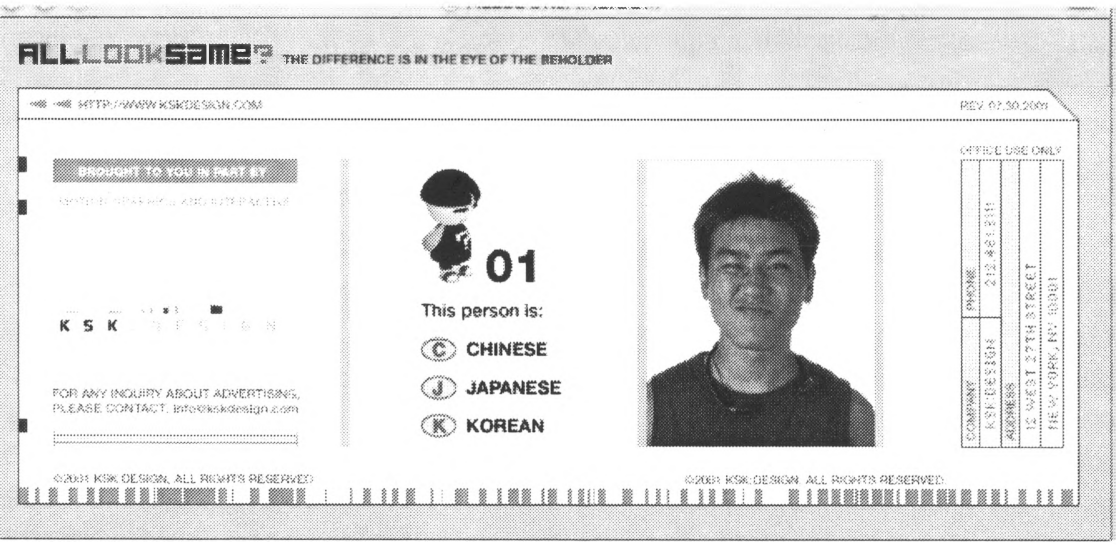


vention into the ways that the visual participates in taxonomies of race.

The most challenging aspect of this, and one which is specifically enabled by this site's interactivity, is that the user is forced to confront her inadequacy in the face of visual "evidence" of race. The low scores that most users get seem to surprise them: in the extremely extensive discussion area of the site where users post their comments, many note that before using the site they thought they could tell the difference, but their low scores convinced them otherwise. ${ }^{9}$ On September 12, 2002, "Annette" posted this particularly thoughtful set of questions to the discussion board:

What does Japanese mean? Does it mean ethnic Koreans, who speak Japanese and no Korean, who are third generation Japanese born? Or is it my friend who is half Japanese, half Korean who grew up in Puerto Rico?? Well maybe it is the children of a Japanese and his Korean Bride.

What does Korean mean? Is is people from southwestern Korea who decended from Chinese in those areas whose names are not Kim and Lee but Chang and Moon??? Or does it mean Koreans who are 1/2 Chinese or Japanese? Nah.. maybe Korean means the child of a Fillipina (or Chinese or Indonesian for that matter) mail order bride (passing as Korean) and her Korean husband. Then again, they could be those in Uzbekistan forcefully moved there by the Russians 50 years ago, or those in eastern China. What about the Mongolians or Manchurians who came across the border to North Korea.. Korean??

And just what does Chinese mean? Those Koreans born of Chinese Decent? Or those who have been in Peenang Malasia for over 100 years, who have mixed with the Indians or Malays at some point?? Or does it mean one of the hundreds of recent Chineese labourers to S. Korea.

WHAT IS MY POINT YOU ASK? Well... None of these groups are "pure" (i.e. no mixture or outside influence), nor are they homogeneous. Even among the Koreans who are considered the most homogeneous most inbred in Asia, there has been some mixture.. that's why it may be difficult to tell... but then... Is it in fact important to tell?????? The world is changing. I, for one, can't wait for the day when there are so many new groups and categories on the census that they will have to drop the race/ethnicity category. ${ }^{10}$

In the face of empirical evidence of the failure of vision as a means of identifying race, "Annette" redirects the conversation in such a way that the categories themselves are deconstructed. Her comment that race and ethnicity will eventually become uncategorizable, and thus unavailable to empirical analysis, takes the site to its logical conclusion.

Alllooksame.com is a very popular website with Asian-Americans. ${ }^{11}$ As a result of the site's success, Suematsu was invited to address the Asian-American Students Association at Harvard University on the topic of "Asian-American community" in March 2002. In his speech, which he reprints on alllooksame.com, he claims to have no interest at all in producing an "Asian-American community," asserts that he is not a member of any such thing because he was born in Japan, and goes on to question the importance or relevance of Asian-American studies as a discipline and Asian-Americanness as a meaningful identity based on anything other than shared racial oppression, the existence of which he professes to doubt. 
It seems that the default whiteness of Web content is so pervasive that these Harvard students were inclined to think that any visual representations at all of Asian-Americans on-line constituted an act of community building. But by calling into question what "Asian" is, at least in visual terms, Suematsu is interrogating the basis upon which racial taxonomies like "Asian" are built, and in so doing is producing a community of a different kind.

By uniting Asian users in the act of deconstructing and questioning their own visual notions of race, alllooksame.com produces a community based on a shared act of interactive self-reflexivity. By discovering that Asian identity is in the "eye of the beholder," as the site asserts, race is detached from biological bodies and reassigned to the realm of the cultural, political, and geographical. Even more to the point, the act of severing the visual as a way of knowing from racial identity addresses a sore point within the Asian-American community; that is, racism between Asians. ${ }^{12}$ In this case, the Internet becomes a site where racial visual essentialism can be critiqued in an active, participatory way with its own built-in apparatus: the test.

Alllooksame.com remediates several cultural institutions allied with race-construction in order to comment upon race as a mistaken notion, one that is more easily gotten wrong than right. The site's iconography invokes the scantron exam, a distinctive feature of Western higher education's obsession with the empirical, as well as the pictorial convention of the mugshot and the lineup, both connected visually with the judicial and legal system. This confluence of the academy and the police in this site gestures towards the participation of both within the system which maintains racial codes. The site also shows that racial codes come from the user as well as the interface or content of the site itself. The site exposes the participation of the user in this construction; it shows how individual acts of viewing and "typing" or clicking create race just as surely as do large institutions such as schools, medical establishments, and the law. Of course, individual acts are inflected by these institutions; when this is acknowledged they come less to seem like personal "choices" and more like part of a complex or dynamic by which race occurs and is instantiated in the everyday.

Asian-Americans use the Internet more than any other ethnic group in America, including whites. According to data gathered in a 2001 study by the Pew Internet and American Life Project, "fully $75 \%$ of English-speaking Asian-Americans have used the Internet. Numbering well over 5 million, these Asian-American Internet users are also the Net's most active users. By comparison, $58 \%$ of white adults, $43 \%$ of African-Americans, and 50\% of English-speaking Hispanics are on-line" (Spooner). This little-known digital divide between Asian-Americans and other ethnic groups in regards to Internet use calls into question, to some extent, prior notions of the Internet as a purely "Western" phenomenon. Postcolonial debates which oppose the stern and noble (but ultimately doomed) cultural authenticists, like Ngugi, against the free-wheeling postmodern hybridity of Salman Rushdie both start from the assumption that the Internet is purely Western because it is 
dominated by American content and interfaces. However, alllooksame.com is the product of an invisible but influential group of American racial minorities: the formulation of the Asian as "model minority" is here replaced, in a sense, by the Asian as poweruser or part of a digital majority. In addition, the site's net effect of destabilizing notions of Asian identity based on visual essentialism works to expose the user to her own participation in creating these categories. Thus, the site unwittingly serves both the authenticists and the hybridicists in that it is "ethnic" content produced by and for a distinctive minority group, yet at the same time it questions that identity by fostering debate and conflict around questions of race and ethnicity.

Ultimately, as Suetmatsu writes, "alllooksame is not a statement. It's a question." New media, such as the Internet, enable this question to remain an open one in ways that older, non-interactive media_-both textual and visual-do not.

\section{Notes}

' In Borderlands/La Frontera, Gloria Anzaldua tells a similar story which identifies academic institutions as places where minority cultures and bodies are subjugated by enforced use of the imperial tongue; that is, English. Indeed, American minority narratives having to do with "foreign" language use being punished in institutional contexts are often framed in terms of trauma to bodies and to cultural identities. See Maxine Hong Kingston's Woman Warrior and Richard Rodriguez's Hunger of Memory for additional examples.

${ }^{2}$ See Joe Lockard's "Resisting Cyber-English" for a discussion of the ways that linguistic imperialism contributes to widening "digital divides." He writes, "English monopolization cuts deeply into the Internet's potential for social empowerment, as a linguistic prior condition for access ensures that Anglophone technology controls the contents of subaltern mouths. Ngugi argues that 'a specific culture is not transmitted through language in its universality but in its particularity as the language of a specific community with a specific history.' Cyber-English acts as a cultural filter from this perspective, a filter that sifts out cultural particularisms and standardizes expressive experience."

${ }^{3}$ In Imaginary Homelands Rushdie does discuss racism as a central problem characteristic of Britain's postcolonial period; he calls it "a crisis of the whole culture, of the society's entire sense of itself" (129). And in his introduction he remarks that he was "accused by both Geoffrey Howe and Norman Tebbit of having equated Britain with Nazi Germany" when they first read the piece, while no other negative response seems to have come from any of the others (5). It seems that Rushdie's position as a public intellectual in Great Britain is much more secure when he leaves discussion of race and racism out of the picture.

${ }^{4}$ See Tom Spooner's “Asian-Americans and the Internet: The Young and the Connected" for more data on the rate of adoption of the Internet according to gender, race, and age.

${ }^{5}$ This is not to say that the Internet is purely a visual form and has no textual elements. Indeed, the Internet started out as a purely textual or ASCII form which was unable to produce any images that didn't originate from a standard QWERTY keyboard. However, radical improvements in bandwidth and PC processing speeds, as well as compression technology, have resulted in an Internet that is becoming increasingly graphical. Text-based applications like e-mail and IM (instant message) are still immensely popular, but it's the Web that made the Internet a mass form. Any study of the contemporary Internet must take the visual into account, but the metaphors we use to talk about the Internet still come from 
the world of text: computer-literacy, web-page or home-page, files and folders are all linguistic tropes that are anchored in the textual. This demonstrates the stubbornness of literary models despite the increasingly visual nature of the Internet.

${ }^{6}$ This debate isn't a productive one, yet its persistence is truly remarkable. It has been mirrored in several disciplines, including women`s studies. In addition, if we equate language purity with cultural purity, if cultural authenticity and identity resides in the written as well as spoken language, there are already large numbers of people who are missing a vital component of their culture: the poor. Literacy in a "native" language and cultural authenticity thus become conflated, which is somewhat ironic considering the valorization of "primitive" non-literate peoples as somehow the most pure and authentic (though most underprivileged) of all.

7 See Anne McClintock's seminal Imperial Leather, Nick Mirzoeff's The Visual Culture Reader, which has a section entitled "Race and Identity in Colonial and Postcolonial Culture," and Sander Gilman's Difference and Pathology: Stereotypes of Sexuality, Race, and Madness, in particular his chapter on the Hottentot Venus. It is important to note that though Mirzoeff"s collection also has a section entitled "Virtuality: Virtual Bodies and Virtual Spaces," the book lacks any analyses of actual websites or specific examples from the Internet.

${ }^{8}$ The Chiapas website is a good example of this.

${ }^{9}$ On August 24, 2001, "Oaken Din" writes,

I am a Chinese guy living in the Los Angeles area. I see Chinese ppl all the time. I'll see Koreans and Japanese ppl here and there when I am out and about in the LA area. There are a lot of Vietnamese, Indonesian, Mongolian, etc. that I bump into. When it comes to telling them apart, I seem to get it right for the most part between Chinese, Korean, and Japanese. But I scored measurably on your test. I got a four. That tells me how much I know. I suck and am forever changed. Thnx for the eye opener. (sic)

${ }^{10}$ Original spelling, grammar, and formatting are reproduced from the original post as faithfully as possible.

"Suematsu claims that the test has been taken over 200,000 times since August 2001, and most of the people who posted to the "discussion" section self-identified as Asian.

${ }^{12}$ Harry Mok remarks that when he first started the test he thought, "this was going to be easy. No problem, I'm Chinese. I can spot Chinese people a mile away. I have the Asian sixth sense, an A-dar." After failing miserably, he includes Suematsu's comment that "[a] lot of time just to be polite or politically correct, people go to a difficult long way to find out [what ethnicity or race you are] .... It's almost like a whether-you're-gay-or-straight kind of thing."

\section{Works Cited}

Achebe, Chinua. "An Image of Africa: Racism in Conrad"s Heart of Darkness." Heart of Darkness: An Authoritative Text, Backgrounds and Sources, Criticism. By Joseph Conrad. Ed. Robert Kimbrough. 3rd ed. New York: Norton, 1988. 251-262.

Anzaldua, Gloria. Borderlands/La Frontera. San Francisco: Aunt Lute Books, 1999.

Chiapas. Independent Media Center, Seattle <http://chiapas.indymedia.org>.

Gilman, Sander. Difference and Pathology: Stereotypes of Sexuality, Race, and Madness. Ithaca: Cornell University Press, 1985.

Kingston, Maxine Hong. Woman Warrior: Memoirs of a Girlhood Among Ghosts. New York: Vintage, 1977. 


\section{IJCS}

Lockard, Joe. "Resisting Cyber-English.” Bad Subjects: Political Education for Everyday Life 24 (Feb. 1996) < http://eserver.org/bs/24/lockard.html>.

Lovink, Geert. Dark Fiber: Tracking Critical Internet Culture. Boston: MIT Press, 2002.

McClintock, Anne. Imperial Leather: Race, Gender, and Sexuality in the Colonial Conquest. New York: Routledge, 1995.

Mirzoeff, Nicholas, ed. The Visual Culture Reader: London: Routledge, 1998.

Mok, Harry. "Testing Out my A-Dar: Trying to Pick Out Who is What." 4 Mar. 2002 <http://www.inthefray.com/200203/imagine/same12/same12.html>.

Ngugi, wa-Thiongo. Moving the Centre: The Struggle for Cultural Freedoms. Portsmouth, NH: James Currey/Heinemann, 1993.

Rodriguez, Richard. Hunger for Memory: The Education of Richard Rodriguez. Boston: D. R. Godine, 1981.

Rushdie, Salman. "Damme, this is the Oriental Scene For You!" The New Yorker 23-30 Jun. 1997: 50, 52, 54, 56-61.

—. Imaginary Homelands. London: Penguin, 1991.

Sardar, Ziauddin. "alt.civilizations.FAQ: Cyberspace as the Darker side of the West." The Cybercultures Reader. Ed. David Bell and Barbara Kennedy. New York: Routledge, 2000. $732-752$.

Spooner, Tom. "Asian-Americans and the Internet: The Young and the Connected." Pew Internet and American Life Project 12 Dec. $2001<\mathrm{http}$ ://www.pewinternet.org>.

Suematsu, Dyske. Alllooksame? 30 Jul. $2001<$ http://www.alllooksame.com>.

"Tales of the Commons Culture: Monica Narula, Awadhendra Sharan and Shuddhabrata Sengupta of Delhi's New Sarai Centre Brainstorm the Modish Concept of the Digital Commons." Mute Magazine 20 (July 2001) <http://www.metamute.com>. 